\title{
Norepinephrine Is Coreleased with Serotonin in Mouse Taste Buds
}

\author{
Yijen A. Huang, ${ }^{1}$ Yutaka Maruyama, ${ }^{1}$ and Stephen D. Roper ${ }^{1,2}$ \\ ${ }^{1}$ Department of Physiology and Biophysics, and ${ }^{2}$ Program in Neuroscience, University of Miami School of Medicine, Miami, Florida 33136
}

\begin{abstract}
ATP and serotonin (5-HT) are neurotransmitters secreted from taste bud receptor (type II) and presynaptic (type III) cells, respectively. Norepinephrine (NE) has also been proposed to be a neurotransmitter or paracrine hormone in taste buds. Yet, to date, the specific stimulus for NE release in taste buds is not well understood, and the identity of the taste cells that secrete NE is not known. Chinese hamster ovary cells were transfected with $\alpha_{1 \mathrm{~A}}$ adrenoceptors and loaded with fura-2 ("biosensors") to detect NE secreted from isolated mouse taste buds and taste cells. Biosensors responded to low concentrations of NE ( $\geq 10 \mathrm{nM})$ with a reliable fura-2 signal. NE biosensors did not respond to stimulation with $\mathrm{KCl}$ or taste compounds. However, we recorded robust responses from NE biosensors when they were positioned against mouse circumvallate taste buds and the taste buds were stimulated with $\mathrm{KCl}$ $(50 \mathrm{~mm}$ ) or a mixture of taste compounds (cycloheximide, $10 \mu \mathrm{M}$; saccharin, $2 \mathrm{~mm}$; denatonium, $1 \mathrm{~mm}$; SC45647, $100 \mu \mathrm{M}$ ). NE biosensor responses evoked by stimulating taste buds were reversibly blocked by prazosin, an $\alpha_{1 \mathrm{~A}}$ receptor antagonist. Together, these findings indicate that taste bud cells secrete NE when they are stimulated. We isolated individual taste bud cells to identify the origin of NE release. NE was secreted only from presynaptic (type III) taste cells and not receptor (type II) cells. Stimulus-evoked $\mathrm{NE}$ release depended on $\mathrm{Ca}^{2+}$ in the bathing medium. Using dual biosensors (sensitive to 5-HT and NE), we found all presynaptic cells secrete $5-\mathrm{HT}$ and $33 \%$ corelease NE with $5-\mathrm{HT}$.
\end{abstract}

Key words: biosensors; taste; serotonin; transmitters; calcium imaging; phospholipase C $\beta 2$

\section{Introduction}

Taste buds are specialized chemosensory organs that transduce chemical stimuli in the oral cavity. Synapses between taste bud cells and primary sensory afferent fibers transmit gustatory signals to the CNS. Several transmitter candidates have been proposed for taste bud synapses, including glutamate (Nagai et al., 1998), serotonin (Huang et al., 2005), acetylcholine (Ogura 2002), neuropeptide Y (Zhao et al., 2005) and ATP (Finger et al., 2005). Of these, only serotonin (5-HT) and ATP have unambiguously been demonstrated to be secreted from taste buds (Huang et al., 2005, 2007; Romanov et al., 2007). There is now direct evidence that 5-HT and ATP are secreted by separate classes of taste cells. Presynaptic (type III) taste cells release 5-HT upon stimulation, and receptor (type II) cells secrete ATP (Huang et al., 2007).

Norepinephrine (NE) has been localized to rodent taste cells and also has been proposed as a candidate neurotransmitter or paracrine hormone in mammalian taste buds (Nagahama and Kurihara, 1985; Herness et al., 2002). Recently, Dvoryanchikov et al. (2007) used reverse transcription-PCR to show that a subset of

\footnotetext{
Received Aug. 29, 2008; revised 0ct. 3, 2008; accepted 0ct. 15, 2008.

This work was supported by National Institute on Deafness and Other Communication Disorders-National Institutes of Health Grant 5R01DC007630. We thank Dr. William Jeffries (Creighton University School of Medicine) for the generous donation of $\alpha_{1 \mathrm{~A}}$ receptor DNA.

Correspondence should be addressed to Dr. Stephen D. Roper, Department of Physiology and Biophysics, University of Miami School of Medicine, 1600 North West 10th Avenue, Miami, FL 33136. E-mail: roper@miami.edu. DOI:10.1523/JNEUROSCI.4187-08.2008

Copyright $\odot 2008$ Society for Neuroscience $\quad$ 0270-6474/08/2813088-06\$15.00/0
}

taste cells expresses the norepinephrine transporter (NET). These authors further showed that lingual epithelium containing taste buds secreted NE when the tissue was depolarized by applying $\mathrm{KCl}$. However, despite these findings there is uncertainty regarding the specific stimuli that evoke NE release from taste buds and ambiguity about which cells secrete NE. Using a novel biosensor cell technique, we have detected NE release in response to taste stimuli and have identified the specific taste cell type that secretes this neurotransmitter.

\section{Materials and Methods}

Biosensor cells. We produced two lines of Chinese hamster ovary (CHO) cells, one stably expressing $\alpha_{1 \mathrm{~A}}$ receptors (hereafter, "NE biosensors") (Jiao et al., 2002) and another stably coexpressing $\alpha_{1 \mathrm{~A}}$ and 5- $\mathrm{HT}_{2 \mathrm{c}}$ receptors (hereafter, "dual biosensors"). We also used 5-HT biosensors and ATP biosensors as described previously (Huang et al., 2005, 2007). Biosensors were loaded with $5 \mu \mathrm{M}$ fura-2 AM as described by Huang et al. (2007). An aliquot of fura-2-loaded, suspended biosensor cells was transferred to a recording chamber (Warner Instruments) containing isolated taste buds and/or isolated taste cells and viewed with an inverted microscope (Olympus; IX 70). Immediately after NE-, 5-HT-, or dual biosensors had settled to the bottom of the chamber they were tested with a single application of 5-HT (3 nM) or NE (10 nM). A highly sensitive biosensor cell was identified and drawn onto a fire-polished glass micropipette with gentle suction for use in testing transmitter release from taste cells.

In separate experiments in the absence of taste buds, we verified that $\mathrm{NE}$ biosensors and dual biosensors do not respond to bath-applied $\mathrm{KCl}$ (50 mM, substituted for equimolar $\mathrm{NaCl}$ ), or a mixture of taste compounds (cycloheximide, $10 \mu \mathrm{m}$; saccharin, $2 \mathrm{~mm}$; SC45647, $0.1 \mathrm{~mm}$; de- 
A

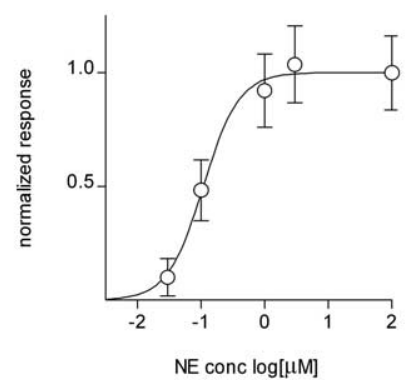

C

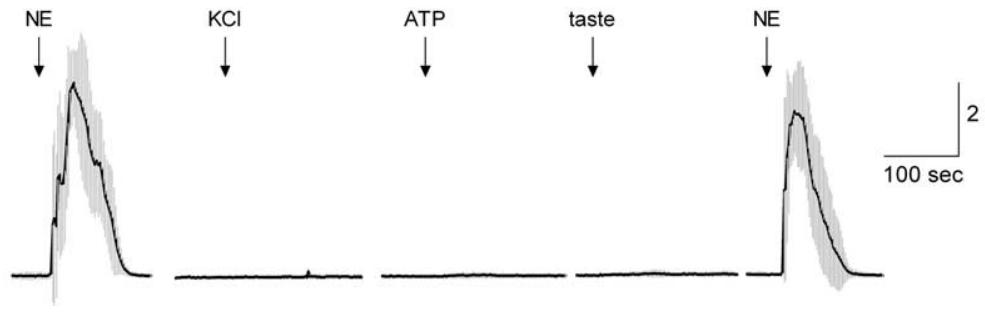

Figure 1. CHO cells stably expressing $\alpha_{1 A}$ receptors respond to bath-applied NE and can be used as NE biosensors. Cells were loaded with fura-2 and $\mathrm{Ca}^{2+}$ mobilization was measured. $\boldsymbol{A}$, Concentration-response relationships for NE. Open circles indicate the mean \pm SEM ( $N=14$ cells). $\boldsymbol{B}$, NE biosensor responses evoked by $1 \mu \mathrm{m}$ ATP to stimulate endogenous purinoceptors and $10 \mathrm{~nm}$ NE to excite transfected $\alpha_{1 \mathrm{~A}}$ receptors. Filled columns, control responses. Open columns, effect of prazosin $(1 \mu \mathrm{M})$, an antagonist of $\alpha_{1 \mathrm{~A}}$ receptors. ATP and NE responses were measured in parallel, and responses were normalized to each agonist (in absence of prazosin) separately. As expected, prazosin selectively abolished the responses evoked by $\mathrm{NE}\left({ }^{* * *} p<0.0001\right)$. C, NE biosensor cells on their own do not respond to $\mathrm{KCl}$ depolarization or to stimulation with ATP or taste compounds. Trace shows mean \pm SEM (gray bars) of $\mathrm{Ca}^{2+}$ responses from NE biosensor cells $(\mathrm{N}=6)$ after incubating with $500 \mu \mathrm{m}$ ATP to desensitize endogenous purinoceptors. NE, $10 \mathrm{~nm} ; \mathrm{KCl}, 50 \mathrm{~mm}$; ATP, $10 \mu \mathrm{m}$; taste, mixture of cycloheximide $(10 \mu \mathrm{M})$, saccharin $(2 \mathrm{~mm})$, SC45647 $(0.1 \mathrm{~mm})$, and denatonium (1 mM). Ordinate, calibration in units of F340/F380 in this and subsequent figures.

natonium, $1 \mathrm{~mm}$ ) (compare Huang et al., 2005, 2007). Prazosin (1 $\mu \mathrm{M})$, an $\alpha_{1 \mathrm{~A}}$ receptor antagonist, was used to verify NE responses in NE and dual biosensor cells. Similarly, mianserin (1 nM), a $5-\mathrm{HT}_{2 \mathrm{c}}$ receptor antagonist, was used to verify and distinguish 5-HT responses in dual biosensors. Prazosin and mianserin were obtained from Sigma.

Isolated taste buds and/or taste cells. Three lines of mice were used in these experiments: C57BL/6J mice (wild-type) of both sexes, transgenic mice expressing enhanced green fluorescent protein (GFP) under control of the PLC $\beta 2$ promoter (PLC $\beta 2$-GFP mice) (Kim et al., 2006), and transgenic mice expressing GFP under the GAD67 promoter (GAD-GFP mice) (Chattopadhyaya et al., 2004). Taste cells that fluoresce green in PLC $\beta 2$-GFP mice identify receptor (type II) cells and those that fluoresce green in GAD-GFP mice identify presynaptic (type III) cells (Kim et al., 2006; Tomchik et al., 2007). Mice were killed following National Institutes of Health guidelines, as approved by the University of Miami Animal Care and Use Committee.

We removed the lingual epithelium containing taste papillae from the tongue by injecting $1 \mathrm{mg} / \mathrm{ml}$ collagenase A (Roche), $2.5 \mathrm{mg} / \mathrm{ml}$ dispase II (Roche), and $1 \mathrm{mg} / \mathrm{ml}$ trypsin inhibitor (Sigma) directly under the epithelium surrounding circumvallate papillae. The peeled epithelium was bathed in $\mathrm{Ca}^{2+}$-free solution $30 \mathrm{~min}$ at room temperature and isolated taste cells were drawn into fire-polished glass micropipettes with gentle suction. Taste cells were transferred to a shallow recording chamber having a glass coverslip base and then loaded with $5 \mu \mathrm{M}$ fura-2 AM. The coverslip was coated with Cell-Tak (BD Biosciences) to hold taste cells firmly attached. Taste buds and/or taste cells were superfused with Tyrode solution (in mM: $140 \mathrm{NaCl}, 5 \mathrm{KCl}, 2 \mathrm{CaCl}_{2}, 1 \mathrm{MgCl}_{2}, 10 \mathrm{HEPES}, 10$ glucose, $10 \mathrm{Na}$-pyruvate, $5 \mathrm{NaHCO}_{3}$, pH7.4, 310-320 Osm). For $\mathrm{Ca}^{2+}$. free Tyrode solution, $\mathrm{MgCl}_{2}$ was substituted for $\mathrm{CaCl}_{2}$ (in mM: $140 \mathrm{NaCl}$, $5 \mathrm{KCl}, 3 \mathrm{MgCl}_{2}, 10 \mathrm{HEPES}, 10$ glucose, $10 \mathrm{Na}$-pyruvate, $5 \mathrm{NaHCO}_{3}, 2$ BAPTA, 2 EGTA, pH7.4, 310-320 Osm).

$\mathrm{Ca}^{2+}$ imaging. For fura-2-loaded biosensor and isolated taste cells, sequential images were recorded at $40 \times$ with a long pass emission filter ( $\geq 510 \mathrm{~nm}$ ) when excited at $340 \mathrm{~nm}$ followed by $380 \mathrm{~nm}$ (Huang et al., 2007). Images were processed with Indec Workbench v5 soft- ware. Data shown are the ratios, F340/F380, indicating relative changes in $\left[\mathrm{Ca}^{2+}\right]_{\mathrm{i}}$.

Stimulation. Isolated taste cells were stimulated by bath-perfusion of $\mathrm{KCl}$ ( $50 \mathrm{~mm}$ substituted equimolar for $\mathrm{NaCl}$ ), taste mix (cycloheximide, $10 \mu \mathrm{M}$; saccharin, $2 \mu \mathrm{mm}$; SC45647, $0.1 \mathrm{~mm}$; denatonium, $1 \mathrm{~mm}$ ), or acetic acid (10 mm). All stimuli were made up in Tyrode solution and applied at $\mathrm{pH} 7.2$, except for acetic acid, which was applied at $\mathrm{pH}$ 5.0.

\section{Results}

To test whether gustatory stimuli excite taste buds to release NE and if so, to identify which taste cells are responsible for the release, we stably transfected $\mathrm{CHO}$ cells with $\alpha_{1 \mathrm{~A}}$ receptors (NE biosensors). NE biosensors were loaded with the $\mathrm{Ca}^{2+}$ sensitive dye fura-2 AM and tested with bath-applied NE (Fig. 1A). Threshold activation was $\sim 10 \mathrm{~nm} \mathrm{NE}$. Concentrationresponse relations indicated that $\mathrm{EC}_{50}$ was $117 \mathrm{nM}$, consistent with published $\mathrm{EC}_{50}$ values (122 nM) for $\alpha_{1 \mathrm{~A}}$ receptors under similar conditions (Jiao et al., 2002). Responses to bath-applied NE were selectively and reversibly abolished by $1 \mu \mathrm{M}$ prazosin (Fig. $1 \mathrm{~B}$ ). We prevented signals from endogenous purinoceptors by incubating NE biosensor cells in $500 \mu \mathrm{M}$ ATP for $30 \mathrm{~min}$ before experiments. This desensitized purinoceptors and rendered the NE biosensors unresponsive to ATP (up to $500 \mu \mathrm{M}$ ). NE biosensor cells did not generate $\mathrm{Ca}^{2+}$ responses to bath-applied $\mathrm{KCl}$ (50 $\mathrm{mm})$, acetic acid (10 mM, pH5), or a mixture of bitter and sweet taste compounds (10 $\mu \mathrm{M}$ cycloheximide, $1 \mathrm{mM}$ denatonium, 2 mm saccharin, $0.1 \mathrm{~mm}$ SC45647, an artificial sweetener) (Fig. 1C). Last, NE biosensors responded to NE when $\mathrm{Ca}^{2+}$ in the medium was replaced with $\mathrm{Mg}^{2+}$ (data not shown), consistent with the coupling of $\alpha_{1 \mathrm{~A}}$ receptors to intracellular $\mathrm{Ca}^{2+}$ release (Jiao et al., 2002; Horinouchi et al., 2007). In short, NE biosensors were highly sensitive, reliable, and specific detectors for norepinephrine.

We tested the ability of isolated mouse vallate taste buds to secrete NE when stimulated. NE biosensors were positioned next to isolated taste buds with a glass manipulator pipette. Depolarizing taste buds with $\mathrm{KCl}(50 \mathrm{~mm})$ generated robust biosensor signals that were abolished in the absence of the extracellular $\mathrm{Ca}^{2+}$ (Fig. 2A) and blocked by prazosin (Fig. $2 B$ ). These findings indicate that stimulating taste buds evokes NE release and that the release of NE is dependent on $\mathrm{Ca}^{2+}$ influx, consistent with synaptic exocytosis. Furthermore, stimulating isolated taste buds with a mixture of taste compounds also elicited NE biosensor responses (Fig. 2C). ATP stimulates taste buds to release 5-HT (Huang et al., 2007). Thus, we tested whether ATP would also evoke NE secretion from isolated taste buds. Bath-applied ATP ( $1 \mu \mathrm{M})$ elicited robust responses of NE biosensors (whose endogenous purinoceptors had been desensitized, see above) indicating that ATP also stimulates taste bud cells to secrete NE (Fig. 2C). Prazosin blocked ATP-evoked NE biosensor responses, verifying that the responses were produced by NE (Fig. 2D). These 
data indicate that $\mathrm{KCl}$ depolarization, taste stimulation, or ATP excitation of taste buds evokes NE secretion.

Isolated taste buds also release seroto$\operatorname{nin}(5-\mathrm{HT})$ when stimulated (Huang et al., 2005). We surveyed isolated taste buds for the relative incidence of 5-HT versus NE release. Using 5-HT biosensors, we found that $\mathrm{KCl}$ evoked 5-HT release in 39\% of isolated taste buds (213 of 540). However, under identical conditions, $\mathrm{KCl}$ depolarization evoked NE release in only $12 \%$ of isolated taste buds ( 6 of 49 ), or $\sim 1 / 3$ the incidence of 5-HT secretion. This difference is highly significant $(p<0.0001$, Fisher's exact test).

We next investigated which taste cell type(s) secreted NE. We isolated individual taste cells, loaded them with fura-2, and measured their responses to taste stimulation and to $\mathrm{KCl}$ depolarization (Huang et al., 2007). Taste bud cells can be differentiated by whether they respond to taste compounds (receptor, type II, cells) or whether they respond to $\mathrm{KCl}$ depolarization (presynaptic, type III, cells) (DeFazio et al., 2006; Huang et al., 2007; Tomchik et al., 2007). We also isolated taste cells from PLC2-GFP mice which express GFP in receptor cells (Kim et al., 2006) and from GAD-GFP mice which express GFP selectively in presynaptic cells (Tomchik et al., 2007) to determine which cells release NE. NE biosensor cells were positioned against identified receptor or presynaptic taste cells to test for NE secretion.

We did not detect NE secretion from receptor cells, despite prominent tasteevoked $\mathrm{Ca}^{2+}$ responses in those cells ( 0 of 17 cells tested). However, NE biosensors showed marked responses when they were positioned against presynaptic cells and the presynaptic cells were stimulated with $\mathrm{KCl}$ or acetic acid (Fig. 3) [ $\mathrm{KCl}$ and acetic acid alike are effective stimuli for presynaptic taste cells (Huang et al., 2005, 2008; Tomchik et al., 2007)]. Although we recorded NE secretion from isolated presynaptic cells, the incidence was low compared with that for 5-HT release. Depolarizing presynaptic cells with $\mathrm{KCl}$ evoked 5 -HT release in $84 \%$ of cells ( 43 of 51 cells), but only $28 \%$ ( 8 of 29 cells) for NE release, or $\sim 1 / 3$ as frequent. These data are consistent with the above findings on NE versus 5-HT release from whole taste buds.

Last, we asked whether presynaptic cells that secreted NE might corelease NE with 5-HT. To study corelease, we used dual biosensor cells that coexpressed serotonergic and adrenergic receptors and thus could report the secretion of 5-HT, or NE, or both. Selective antagonists allowed us to distinguish which biosensor receptors were activated and thus identify the source of the responses. Dual biosensors were positioned next to presynaptic cells and the presynaptic cells were depolarized with $\mathrm{KCl}$, as above. When we observed a dual biosensor responding to this procedure, we applied mianserin to block the biosensor's serotonergic receptors. In most cases, mianserin totally abolished $\mathrm{KCl}$-evoked dual biosensor signals, indicat-
B
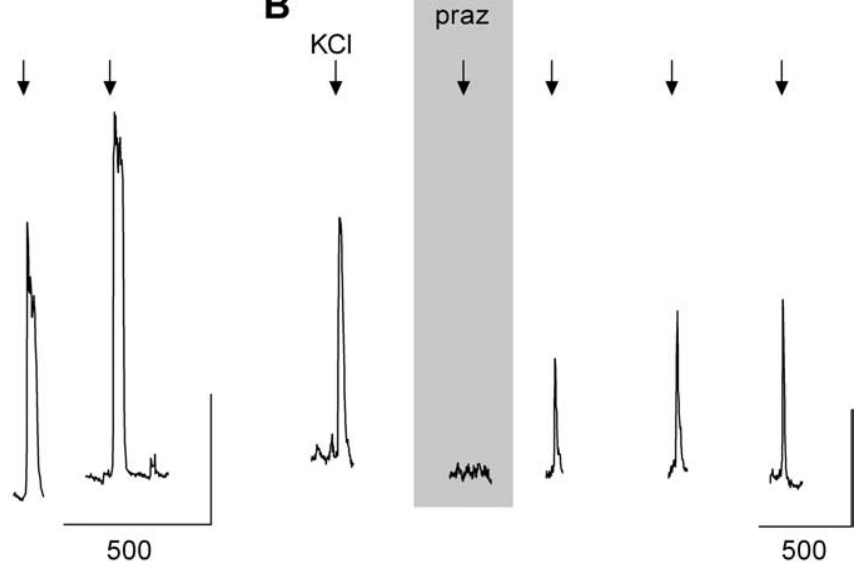

D
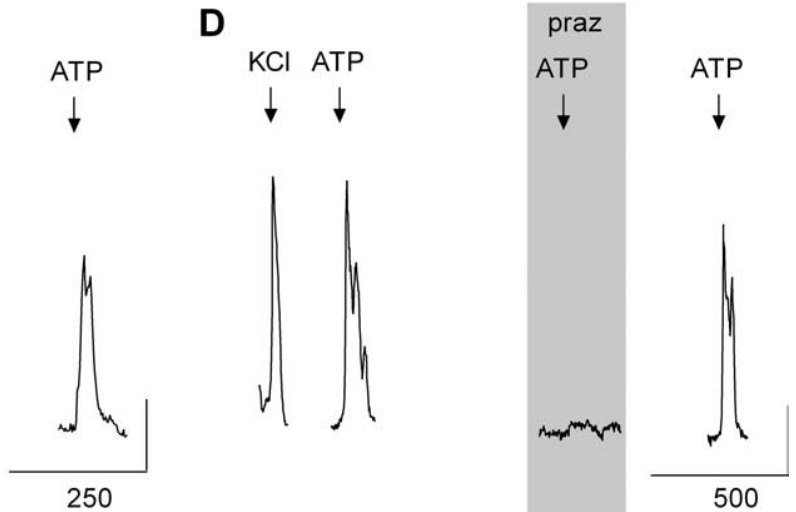

Figure 2. Stimulating taste buds evokes Ca-dependent release of norepinephrine. $A$, An NE biosensor cell positioned against a cell purinoceptors. In all cases, endogenous biosensor cell purinoceptors were desensitized before the experiments, as described in Materials and Methods. Calibration: vertical, 0.5; horizontal, seconds, as marked.

ing that $\mathrm{KCl}$ stimulation had evoked 5 -HT release (Fig. $4 \mathrm{~A}$ ) (see also Huang et al., 2005, their Fig. 1C). However, in 4 of 13 experiments, mianserin only partially blocked the dual biosensor response. In these experiments, adding prazosin (in presence of manserin) to block biosensor adrenoceptors completely eliminated the biosensor responses (Fig. $4 B$ ). We also conducted the reverse sequence: prazosin followed by prazosin plus mianserin. Prazosin alone did not eliminate biosensor responses to presynaptic cell stimulation in any experiments. Collectively, these findings suggest that when depolarized with $\mathrm{KCl}$, all presynaptic cells secrete 5 -HT but $\sim 1 / 3$ corelease NE and 5-HT.

Recently, Heath et al. (2006) reported that human taste thresholds were lowered by circulating NE. Accordingly, we tested whether bath applying NE to isolated mouse taste bud cells affected excitation and transmitter secretion from receptor (type II) or presynaptic (type III) cells. We isolated and identified taste cells, used ATP biosensors (for receptor cells) or 5-HT biosensors [for presynaptic cells, as described by Huang et al. (2007)], and applied NE. Based on our observations that applying $10 \mathrm{~nm}$ NE calibration doses to NE biosensors evoked responses equal to or much larger than those generated by NE release from presynaptic cells (Fig. 3C), we 
A

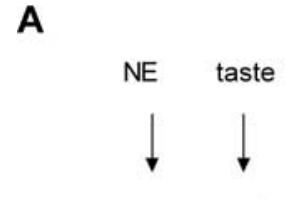

B

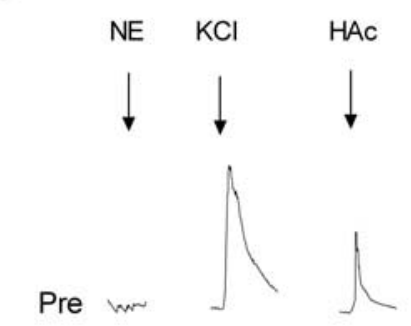

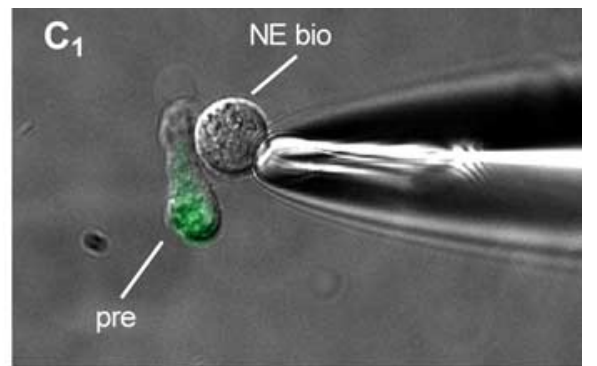

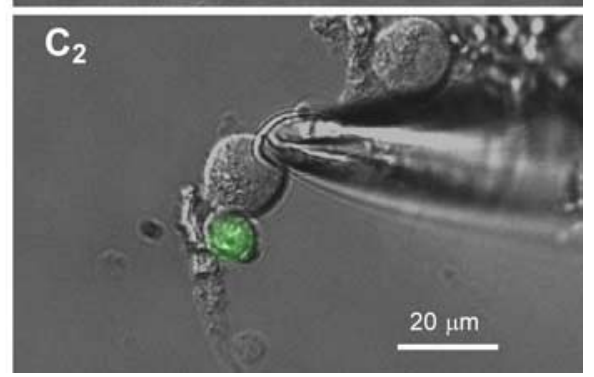

Figure 3. Presynaptic (type III) taste cells, but not receptor (type II) cells, secrete NE. GAD-GFP mice were used to isolate and identify individual presynaptic taste cells; PLC $\beta 2$-GFP mice were used to identify receptor taste cells. $\boldsymbol{A}$, Receptor cells do not secrete NE. The pair of traces shows simultaneous $\mathrm{Ca}^{2+}$ recordings in a receptor taste cell (Rec) and an apposed NE biosensor cell (NE bio). NE (10 nm) was applied first to verify biosensor sensitivity. Taste stimulation was a mixture, as in Figure 2. B, Presynaptic cells secrete NE. Stimulus-evoked responses are from the presynaptic cell shown in $\mathrm{C}_{2}$ (next). Stimulating with $\mathrm{KCl}\left(50 \mathrm{~mm}\right.$ ) or acetic acid ("HOAc," $10 \mathrm{~mm}, \mathrm{pH} 5.0$ ) triggered Ca ${ }^{2+}$ responses in the presynaptic cell (Pre) and NE release (NE bio). As in $A$, $10 \mathrm{~nm} \mathrm{NE} \mathrm{was} \mathrm{applied} \mathrm{initially}$ to validate the NE biosensor. C, Fluorescence and interference contrast optics micrographs showing a NE biosensor ("NE-bio") apposed to identified presynaptic cell (i.e., expressing GFP, "pre"). Traces in $\boldsymbol{B}$ were taken from the presynaptic cell shown in $\boldsymbol{C}_{2}$. Note that debris attached to cells in $C_{2}$ did not interfere with responses.

estimated that stimulus-evoked NE in interstitial spaces within taste buds in situ might reach or exceed $10 \mathrm{nM}$. Nevertheless, we tested bath-applied NE up to $100 \mu \mathrm{M}$. In no case were receptor or presynaptic cell responses $\left(\mathrm{Ca}^{2+}\right.$ mobilization) altered by NE. Further, NE did not alter stimulus-evoked secretion of ATP or 5-HT (Fig. 5). We conclude that NE acts on targets in the taste bud other than receptor and presynaptic taste cells, perhaps sensory nerve terminals or type I taste cells. This question remains to be tested.

\section{Discussion}

This report shows that NE is a neurotransmitter in mammalian taste buds. Isolated taste buds cells secrete NE in response to taste stimulation. The cells responsible for NE release comprise a subset of presynaptic (type III) taste cells. NE appears to be coreleased with 5-HT.

We previously reported that taste cells that respond to sweet and bitter taste compounds, i.e., receptor (type II) cells, secrete ATP through pannexin 1 hemichannels in response to taste stimulation (Huang et al., 2007). Moreover, taste-evoked secretion of ATP excites presynaptic (type III) cells and causes them to release 5-HT, indicating cell-to-cell communication between receptor and presynaptic cells within taste buds. Thus, the likely explanation for taste-evoked NE secretion from isolated taste buds (Fig. $2 B$ ) is that NE release is secondary to taste stimulation of receptor cells, release of ATP, and subsequent excitation of presynaptic cells, just as the case for 5-HT release.

The findings reported by Heath et al. (2006) on NE modulation of human taste threshold emphasize the importance of noradrenergic mechanisms in the peripheral sensory organs of taste. However, the specific postsynaptic target(s) for NE remain to be determined. Herness and Sun (1999) and Herness et al. (2002) reported that NE inhibits $\mathrm{K}^{+}$currents and enhances $\mathrm{Cl}^{-}$currents in taste cells from rats. They also reported that applying $\mathrm{NE}$ evoked intracellular $\mathrm{Ca}^{2+}$ transients in $\sim 17 \%$ of taste cells, but without identifying cell type. Herness et al. (2002) concluded that NE may play a modulatory role in taste buds. However, we found no evidence for effects of NE on stimulus-evoked neurotransmitter (ATP, 5-HT) release in mouse taste buds nor any evidence for NE-evoked $\mathrm{Ca}^{2+}$ mobilization in taste cells. If NE modulates taste bud function in mouse taste buds as reported for rat (Herness et al., 2002), NE must act on mechanisms other than ATP and 5-HT release, or act on cells other than receptor (type II) and presynaptic (type III) cells. NE was reported to enhance gustatory nerve responses in frogs (Morimoto and Sato, 1982; Nagahama and Kurihara, 1985), raising the possibility that gustatory afferent fibers are the targets for taste-stimulated NE secretion in taste buds. Our experiments were not designed to test this possibility and this remains an intriguing possibility.

Based on the RT-PCR and immunohistochemical data, Dvoryanchikov et al. (2007) reported that biosynthetic enzymes for NE, tyrosine hydroxylase and dopamine $\beta$-hydroxylase, are not present in mouse taste buds. They concluded that the source of NE in taste buds is cellular uptake from interstitial spaces. Those workers also reported that $\mathrm{KCl}$ stimulation of lingual tissues elicited NE release, presumably from NE uptake into taste cells. Ultrastructural studies have shown that there are adrenergic fibers in and around taste buds (Yoshie et al., 1996, rat; Reutter and Witt, 2004, fish), possibly representing efferent sympathetic innervation and a potential source of NE for taste buds. Dvoryanchikov et al. (2007) found that a subset of presynaptic cells in mouse taste buds express the NET, thus providing a mechanism for NE uptake. Our findings are consistent with those results, namely that a subset of presynaptic cells take up and secrete NE upon stimulation.

Our data indicate that the majority or all presynaptic (type III) taste cells secrete 5 -HT upon stimulation but only $\sim 1 / 3$ of them corelease NE with 5-HT. We found no instance of NE secretion alone. One interpretation is that there are 3-5 times as many serotonergic presynaptic cells as there are NE/5-HT-secreting 


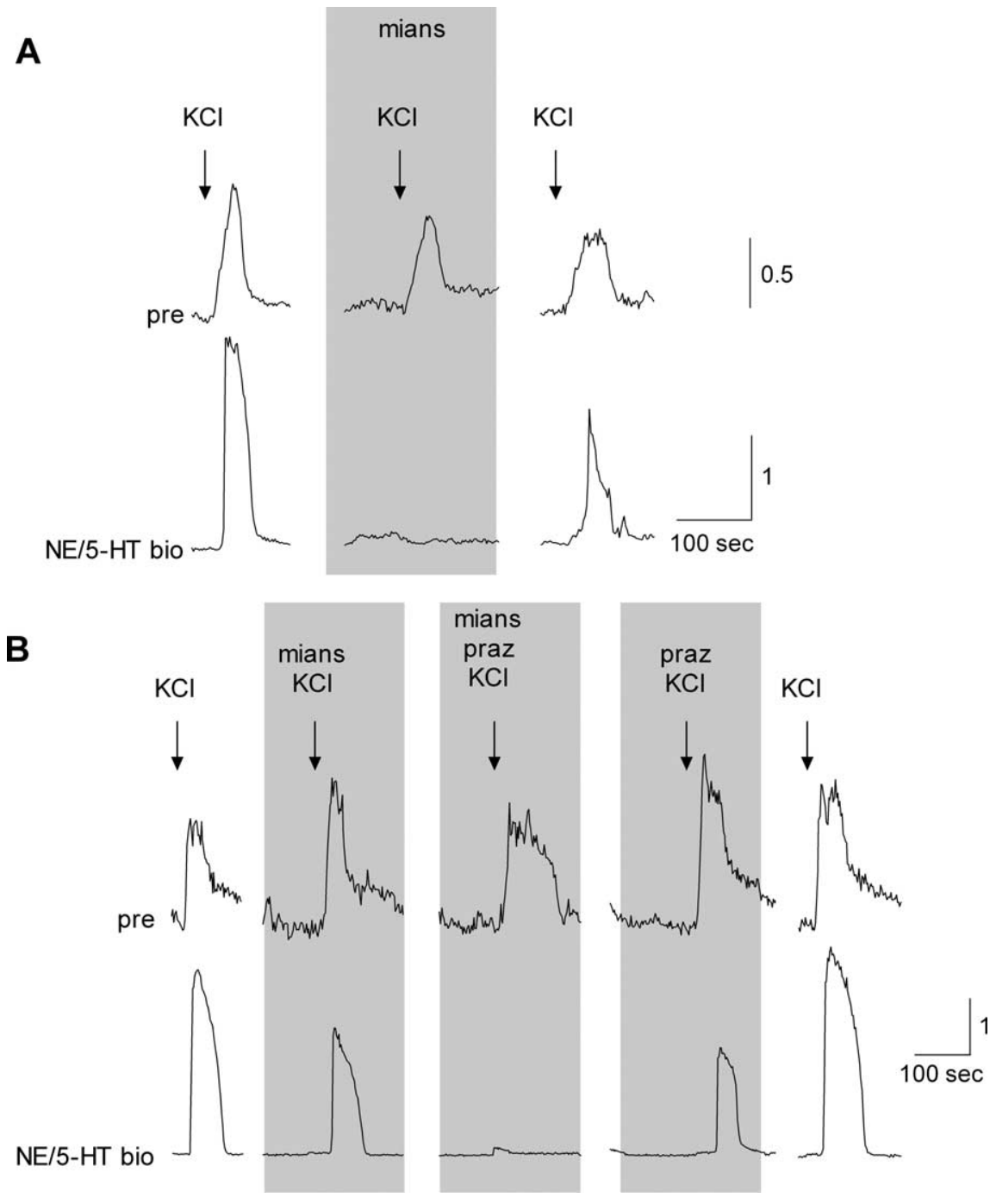

Figure 4. A subset of presynaptic (type III) taste cell corelease 5-HT and NE. Individual presynaptic taste cells were isolated and identified and tested for transmitter release with a dual biosensor, sensitive to either NE or 5-HT (NE- and 5-HT biosensor), as described in Materials and Methods. As in Figure 3, simultaneous recordings were made from a presynaptic cell and an apposed dual biosensor. $\boldsymbol{A}, \mathrm{KCl}$ depolarization triggered $\mathrm{Ca}^{2+}$ responses in the presynaptic cell (pre; top) and evoked NE release (NE/5-HT bio; bottom). Mianserin ("mian," $1 \mathrm{nM}$ ), a 5- $\mathrm{HT}_{2 \mathrm{c}}$ receptor antagonist, reversibly blocked the dual biosensor cell responses, indicating that in this case, the presynaptic cell only released 5 -HT. $\boldsymbol{B}$, In other cases (4 of 13), mianserin or prazosin ("praz," $1 \mu \mathrm{M}$ ) alone only partially blocked responses from the dual biosensor, but adding mianserin together with prazosin strongly inhibited dual biosensor responses. This finding indicates that in some cases, stimulating presynaptic taste cells coreleases 5 -HT and NE.

cells. Another interpretation is that 5-HT is secreted diffusely over the entire presynaptic cell surface but NE is released only at discrete foci, such as at the synapses that these cells, and only these cells, possess (Yang et al., 2000; Yee et al., 2001; Clapp et al., 2006). According to this interpretation, a biosensor cell positioned anywhere near a presynaptic cell would be likely to detect 5-HT release, but NE secretion would only be recorded when the biosensor was positioned in close proximity to a synaptic release site. Such a possibility, as well as further information about the molecular mechanisms of 5-HT and NE release is currently under investigation.

\section{References}

Chattopadhyaya B, Di Cristo G, Higashiyama H, Knott GW, Kuhlman SJ, Welker E, Huang ZJ (2004) Experience and activity-dependent maturation of perisomatic GABAergic innervation in primary visual cortex during a postnatal critical period. J Neurosci 24:9598-9611.
Clapp TR, Medler KF, Damak S, Margolskee RF, Kinnamon SC (2006) Mouse taste cells with $\mathrm{G}$ protein-coupled taste receptors lack voltagegated calcium channels and SNAP-25. BMC Biol 4:7.

DeFazio RA, Dvoryanchikov G, Maruyama Y, Kim JW, Pereira E, Roper SD, Chaudhari N (2006) Separate populations of receptor cells and presynaptic cells in mouse taste buds. J Neurosci 26:3971-3980.

Dvoryanchikov G, Tomchik SM, Chaudhari N (2007) Biogenic amine synthesis and uptake in rodent taste buds. J Comp Neurol 505:302-313.

Finger TE, Danilova V, Barrows J, Bartel DL, Vigers AJ, Stone L, Hellekant G, Kinnamon SC (2005) ATP signaling is crucial for communication from taste buds to gustatory nerves. Science 310:1495-1499.

Heath TP, Melichar JK, Nutt DJ, Donaldson LF (2006) Human taste thresholds are modulated by serotonin and noradrenaline. J Neurosci 26:12664-12671.

Herness MS, Sun XD (1999) Characterization of chloride currents and their noradrenergic modulation in rat taste receptor cells. J Neurophysiol 82:260-271.

Herness S, Zhao FL, Kaya N, Lu SG, Shen T, Sun XD (2002) Adrenergic signalling between rat taste receptor cells. J Physiol 543:601-614.

Horinouchi T, Miyake Y, Nishiya T, Nishimoto A, Yorozu S, Jinno A, Kajita E, Miwa S (2007) Characterization of noradrenaline-induced increases in intracellular $\mathrm{Ca} 2+$ levels in Chinese hamster ovary cells stably expressing human alphalA-adrenoceptor. J Pharmacol Sci 105:103-111.

Huang YA, Maruyama Y, Stimac R, Roper SD (2008) Presynaptic (Type III) cells in mouse taste buds sense sour (acid) taste. J Physiol 586:2903-2912.

Huang YJ, Maruyama Y, Lu KS, Pereira E, Plonsky I, Baur JE, Wu D, Roper SD (2005) Mouse taste buds use serotonin as a neurotransmitter. J Neurosci 25:843-847.

Huang YJ, Maruyama Y, Dvoryanchikov G, Pereira E, Chaudhari N, Roper SD (2007) The role of pannexin 1 hemichannels in ATP release and cell-cell communication in mouse taste buds. Proc Natl Acad Sci USA 104:6436-6441.

Jiao X, Gonzalez-Cabrera PJ, Xiao L, Bradley ME, Abel PW, Jeffries WB (2002) Tonic inhibitory role for cAMP in alpha(1a)-adrenergic receptor coupling to extracellular signalregulated kinases 1/2. J Pharmacol Exp Ther 303:247-256.

Kim JW, Roberts C, Maruyama Y, Berg S, Roper S, Chaudhari N (2006) Faithful expression of GFP from the PLCbeta2 promoter in a functional class of taste receptor cells. Chem Senses 31:213-219.

Morimoto K, Sato M (1982) Role of monoamines in afferent synaptic transmission in frog taste organ. Jpn J Physiol 32:855-871.

Nagahama S, Kurihara K (1985) Norepinephrine as a possible transmitter involved in synaptic transmission in frog taste organs and Ca dependence of its release. J Gen Physiol 85:431-442.

Nagai T, Delay RJ, Welton J, Roper SD (1998) Uptake and release of neurotransmitter candidates, $[3 \mathrm{H}]$ serotonin, $[3 \mathrm{H}]$ glutamate, and $[3 \mathrm{H}]$ gammaaminobutyric acid, in taste buds of the mudpuppy, Necturus maculosus. J Comp Neurol 392:199-208.

Ogura T (2002) Acetylcholine increases intracellular Ca2 + in taste cells via activation of muscarinic receptors. J Neurophysiol 87:2643-2649.

Reutter K, Witt M (2004) Are there efferent synapses in fish taste buds? J Neurocytol 33:647-656. 


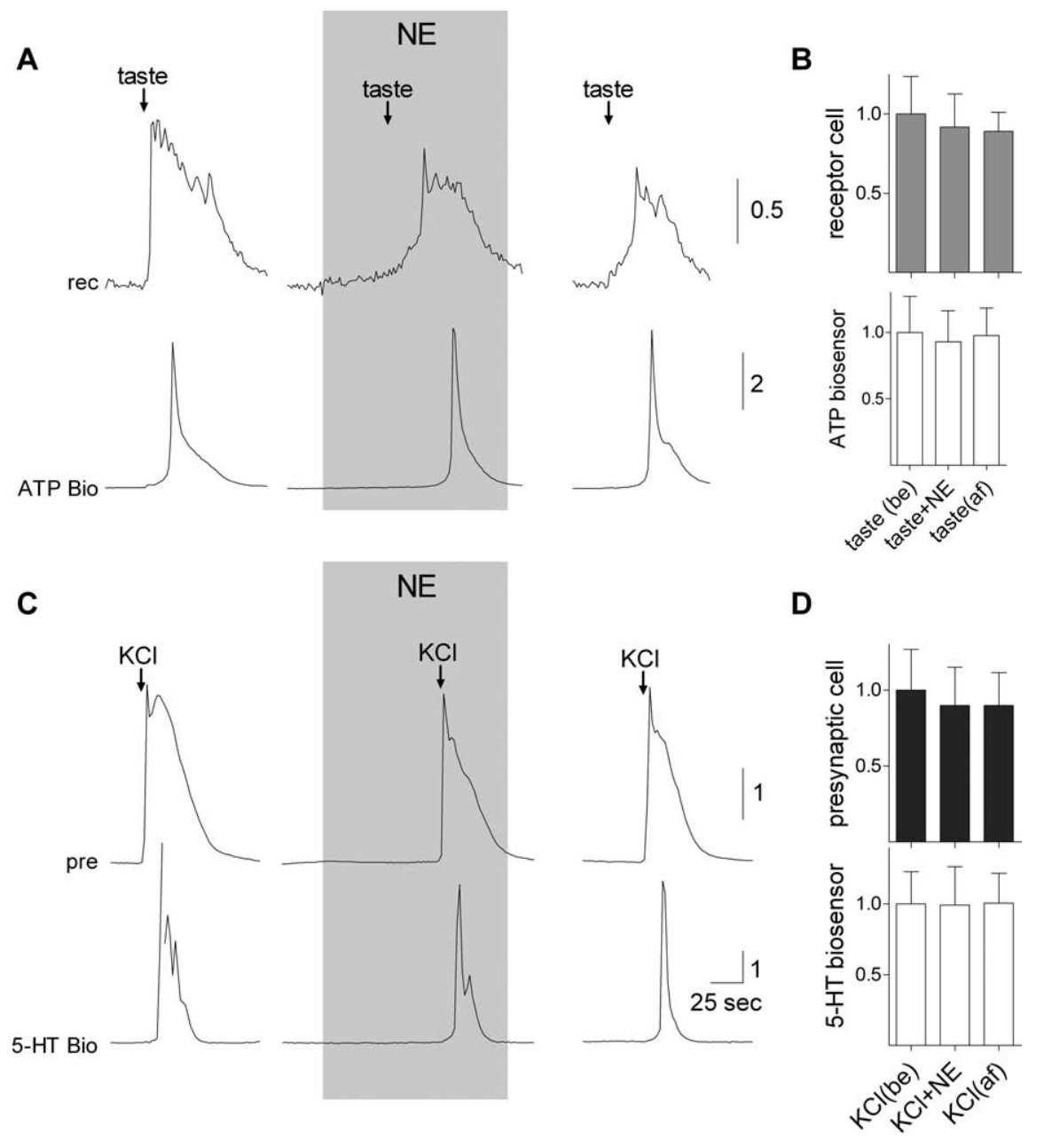

Figure 5. Norepinephrine does not affect stimulus-evoked transmitter release (ATP, 5-HT) from receptor (type II) or presynaptic (type III) taste cells. $\boldsymbol{A}$, Simultaneous recordings from an isolated taste receptor cell (top) and an apposed ATP-biosensor to monitor transmitter secretion during taste stimulation (Fig. 2). Taste-evoked responses in the receptor cell and ATP secretion were unaffected in the presence of even relatively high concentrations of NE (100 $\mu \mathrm{M}$; shaded area). B, Summary of the effects of NE on taste receptor cells and taste-evoked ATP secretion. Error bars represent mean \pm SEM of taste-evoked responses in receptor cells (gray bars) and in ATP biosensors (white bars) ( $N=6$ cells). Individual responses were normalized to the (pooled) average taste evoked responses for all experiments in this series. No significant effects were of applying NE. C, Similarly, comparable recordings taken from an isolated presynaptic taste cell, and an apposed 5-HT biosensor cell showed no effects of applying $100 \mu \mathrm{m}$ NE. D, As in $\boldsymbol{B}$, summary of data from eight cells showing the lack of effect of NE on $\mathrm{KCl}$-evoked responses in presynaptic cells and in stimulus-evoked 5-HT release.

Romanov RA, Rogachevskaja OA, Bystrova MF, Jiang P, Margolskee RF, Kolesnikov SS (2007) Afferent neurotransmission mediated by hemichannels in mammalian taste cells. EMBO J 26:657-667.

Tomchik SM, Berg S, Kim JW, Chaudhari N, Roper SD (2007) Breadth of tuning and taste coding in mammalian taste buds. J Neurosci 27:10840-10848.

Yang R, Crowley HH, Rock ME, Kinnamon JC (2000) Taste cells with synapses in rat circumvallate papillae display SNAP-25-like immunoreactivity. J Comp Neurol 424:205-215.
Yee CL, Yang R, Böttger B, Finger TE, Kinnamon JC (2001) "Type III" cells of rat taste buds: immunohistochemical and ultrastructural studies of neuron-specific enolase, protein gene product 9.5, and serotonin. J Comp Neurol 440:97-108.

Yoshie S, Kanazawa H, Fujita T (1996) A possibility of efferent innervation of the gustatory cell in the rat circumvallate taste bud. Arch Histol Cytol 59:479-484.

Zhao FL, Shen T, Kaya N, Lu SG, Cao Y, Herness S (2005) Expression, physiological action, and coexpression patterns of neuropeptide $\mathrm{Y}$ in rat taste-bud cells. Proc Natl Acad Sci U S A 102: $11100-11105$. 